\title{
Anthropogenic carbon dioxide source areas observed from space: assessment of regional enhancements and trends
}

\author{
O. Schneising, J. Heymann, M. Buchwitz, M. Reuter, H. Bovensmann, and J. P. Burrows \\ Institute of Environmental Physics (IUP), University of Bremen FB1, Bremen, Germany \\ Correspondence to: O. Schneising (oliver.schneising@iup.physik.uni-bremen.de) \\ Received: 13 November 2012 - Published in Atmos. Chem. Phys. Discuss.: 6 December 2012 \\ Revised: 21 February 2013 - Accepted: 22 February 2013 - Published: 4 March 2013
}

\begin{abstract}
Urban areas, which are home to the majority of today's world population, are responsible for more than twothirds of the global energy-related carbon dioxide emissions. Given the ongoing demographic growth and rising energy consumption in metropolitan regions particularly in the developing world, urban-based emissions are expected to further increase in the future. As a consequence, monitoring and independent verification of reported anthropogenic emissions is becoming more and more important.

It is demonstrated using SCIAMACHY nadir measurements that anthropogenic $\mathrm{CO}_{2}$ emissions can be detected from space and that emission trends might be tracked using satellite observations. This is promising with regard to future satellite missions with high spatial resolution and wide swath imaging capability aiming at constraining anthropogenic emissions down to the point-source scale.

By subtracting retrieved background values from those retrieved over urban areas we find significant $\mathrm{CO}_{2}$ enhancements for several anthropogenic source regions, namely $1.3 \pm 0.7 \mathrm{ppm}$ for the Rhine-Ruhr metropolitan region and the Benelux, $1.1 \pm 0.5 \mathrm{ppm}$ for the East Coast of the United States, and $2.4 \pm 0.9 \mathrm{ppm}$ for the Yangtze River Delta. The order of magnitude of the enhancements is in agreement with what is expected for anthropogenic $\mathrm{CO}_{2}$ signals. The larger standard deviation of the retrieved Yangtze River Delta enhancement is due to a distinct positive trend of $0.3 \pm$ $0.2 \mathrm{ppm} \mathrm{yr}^{-1}$, which is quantitatively consistent with anthropogenic emissions from the Emission Database for Global Atmospheric Research (EDGAR) in terms of percentual increase per year.
\end{abstract}

Potential contributions to the retrieved $\mathrm{CO}_{2}$ enhancement by several error sources, e.g. aerosols, albedo, and residual biospheric signals due to heterogeneous seasonal sampling, are discussed and can be ruled out to a large extent.

\section{Introduction}

The most important anthropogenic greenhouse gas carbon dioxide $\left(\mathrm{CO}_{2}\right)$, which contributes substantially to global climate change, has increased significantly since pre-industrial times with atmospheric abundance now being about $40 \%$ higher compared to the level of 1750 primarily as a result of fossil fuel combustion, cement production, land use change (mainly deforestation), and other human activities. This steady increase has been well documented by the Intergovernmental Panel on Climate Change (IPCC) (Solomon et al., 2007). As global warming is regarded as a serious threat to our planet, efforts to limit anthropogenic emissions have started. Legislation of many nations and the multilateral Kyoto protocol require monitoring, reporting, and independent verification of $\mathrm{CO}_{2}$ emissions. However, compliance and realisation remain challenging. Current emission inventories are typically based on economic and technical information and only to a lesser extent on direct measurements up to now. Global satellite measurements have the potential to support the monitoring, verification, and transparency of international environmental policy in the post Kyoto era. In a recent study, McKain et al. (2012) argue that observations of column-averaged carbon dioxide, e.g. from space, are presumably the most suitable method to detect emissions and emission trends from urban regions. 
Theoretical analyses have shown that satellite measurements combined with inverse modelling can significantly reduce surface flux uncertainties provided that the satellite data are accurate and precise enough (Rayner and O'Brien, 2001; Houweling et al., 2004; Miller et al., 2007; Chevallier et al., 2007; Hungershoefer et al., 2010). The significant reduction of regional-scale flux uncertainties additionally requires high sensitivity to the lowest atmospheric layers where the variability is largest. Sensitivity to all altitude levels, including the boundary layer, can be achieved by using reflected solar radiation in the near-infrared/shortwave-infrared (NIR/SWIR) spectral region. SCIAMACHY onboard ENVISAT (launched in 2002, end of mission declared in 2012) (Burrows et al., 1995; Bovensmann et al., 1999) was the first and is with TANSO onboard GOSAT (launched in 2009) (Kuze et al., 2009) one of only two satellite instruments yielding measurements of the relevant absorption bands of $\mathrm{CO}_{2}$ in this spectral range. OCO-2 (to be launched in 2014) (Crisp et al., 2004; Boesch et al., 2011) will be another satellite designed to observe atmospheric carbon dioxide in the same spectral region as SCIAMACHY and TANSO.

While these instruments primarily aim at providing additional constraints on natural $\mathrm{CO}_{2}$ sources and sinks, CarbonSat (Bovensmann et al., 2010), which is one of two candidate Earth Explorer Opportunity Missions (EE-8, to be launched in 2019), is designed to additionally monitor anthropogenic point source emissions explicitly by making use of high spatial resolution $\left(2 \times 2 \mathrm{~km}^{2}\right)$ and wide swath imaging capability (goal $500 \mathrm{~km}$ ). It has been shown that one CarbonSat or a CarbonSat Constellation will be able to independently verify emissions from large individual power plants (Velazco et al., 2011). Nevertheless, first results concerning urban $\mathrm{CO}_{2}$ emissions from column-averaged mole fractions retrieved from satellite data were already derived using SCIAMACHY (Schneising et al., 2008, case study for Central Europe) and GOSAT (Kort et al., 2012, case study for Los Angeles and Mumbai) despite either coarser spatial resolution (SCIAMACHY) or sparsely distributed measurements (GOSAT). Recently, another analysis discussing regional contrasts of carbon dioxide mole fractions retrieved from GOSAT with regard to fossil fuel emissions has been performed independently (Keppel-Aleks et al., 2012).

In this study, we present an extensive analysis of large emitting urban agglomerations using SCIAMACHY nadir measurements demonstrating that anthropogenic emissions and emission trends can be detected from space.

\section{Data set}

We analyse column-averaged dry air mole fractions of atmospheric carbon dioxide (denoted $\mathrm{XCO}_{2}$ ) retrieved from SCIAMACHY onboard ENVISAT using Weighting Function Modified DOAS (WFM-DOAS) (Schneising et al., 2011,2012 ) for the period from 2003 to 2009 . The data set is based on WFMD v2.2 described in Heymann et al. (2012b). To focus on regional variations due to anthropogenic emissions an additional (post-processing) correction based on multivariate linear regression similar to Wunch et al. (2011) is applied to minimise residual systematic retrieval biases. More precisely, we analysed correlations of the difference of the WFMD retrievals to the assimilation system CarbonTracker (Peters et al., 2007, 2010) for the year 2004 at 8 locations (Białystok, Bremen, Orléans, Park Falls, Lamont, Darwin, Wollongong, and Lauder) with state vector and parameter vector elements or instrument and atmospheric parameters. As CarbonTracker is constrained by numerous reference measurements near the selected northern hemispheric locations and the $\mathrm{XCO}_{2}$ seasonal cycle on the Southern Hemisphere is small, it is assumed that the found correlations represent systematic retrieval errors existing all over the world and at all times. Hence, the following correction is applied on Level 2 basis for the entire global multi-year data set universally:

$$
\begin{aligned}
\mathrm{XCO}_{2}^{\mathrm{cor}} & =\mathrm{XCO}_{2}-34.8 \frac{\mathrm{ppm}}{\%} \cdot \mathrm{O}_{2}^{\mathrm{err}}-13.9 \mathrm{ppm} \cdot I \\
& -0.9 \mathrm{ppm} \frac{\mathrm{cm}^{2}}{\mathrm{~g}} \cdot \mathrm{H}_{2} \mathrm{O}+1.9 \frac{\mathrm{ppm}}{\%} \cdot \mathrm{CO}_{2}^{\mathrm{err}} \\
& -1.2 \frac{\mathrm{ppm}}{\mathrm{km}} \cdot h-120 \mathrm{ppm} \cdot t+140 \mathrm{ppm}
\end{aligned}
$$

Thereby, $\mathrm{O}_{2}^{\text {err }}$ and $\mathrm{CO}_{2}^{\text {err }}$ are the column errors in \% estimated from fit quality and the diagonal elements of the covariance matrix (Schneising et al., 2008), $I$ is the sunnormalised radiance at $1560 \mathrm{~nm}, \mathrm{H}_{2} \mathrm{O}$ is the retrieved water vapour vertical column amount in $\mathrm{g} \mathrm{cm}^{-2}, h$ is the average altitude of the observed surface in $\mathrm{km}$, and $t$ is the SCIAMACHY nadir throughput at $750 \mathrm{~nm}$ derived by solar measurements. The resulting data set is referred to as WFMDv2.3. Corresponding hemispheric means are shown in Fig. 1 demonstrating that the steady increase of atmospheric carbon dioxide of just less than $2 \mathrm{ppm} \mathrm{yr}^{-1}$, which is attributed to anthropogenic emissions and quantitatively in line with expectations, can be clearly observed. Also visible is the pronounced seasonal cycle on the Northern Hemisphere due to growing and decaying vegetation. This data set is used in the following to analyse anthropogenic source regions.

\section{Results}

\subsection{Estimation of local anthropogenic enhancements}

To determine if regionally elevated $\mathrm{CO}_{2}$ originating from anthropogenic emissions can be detected, we selected the three important $\mathrm{CO}_{2}$ source regions shown in Fig. 2 exhibiting the largest emissions in their respective continents: the RhineRuhr metropolitan region and the Benelux in Central Europe, the East Coast of the United States, and the Yangtze 

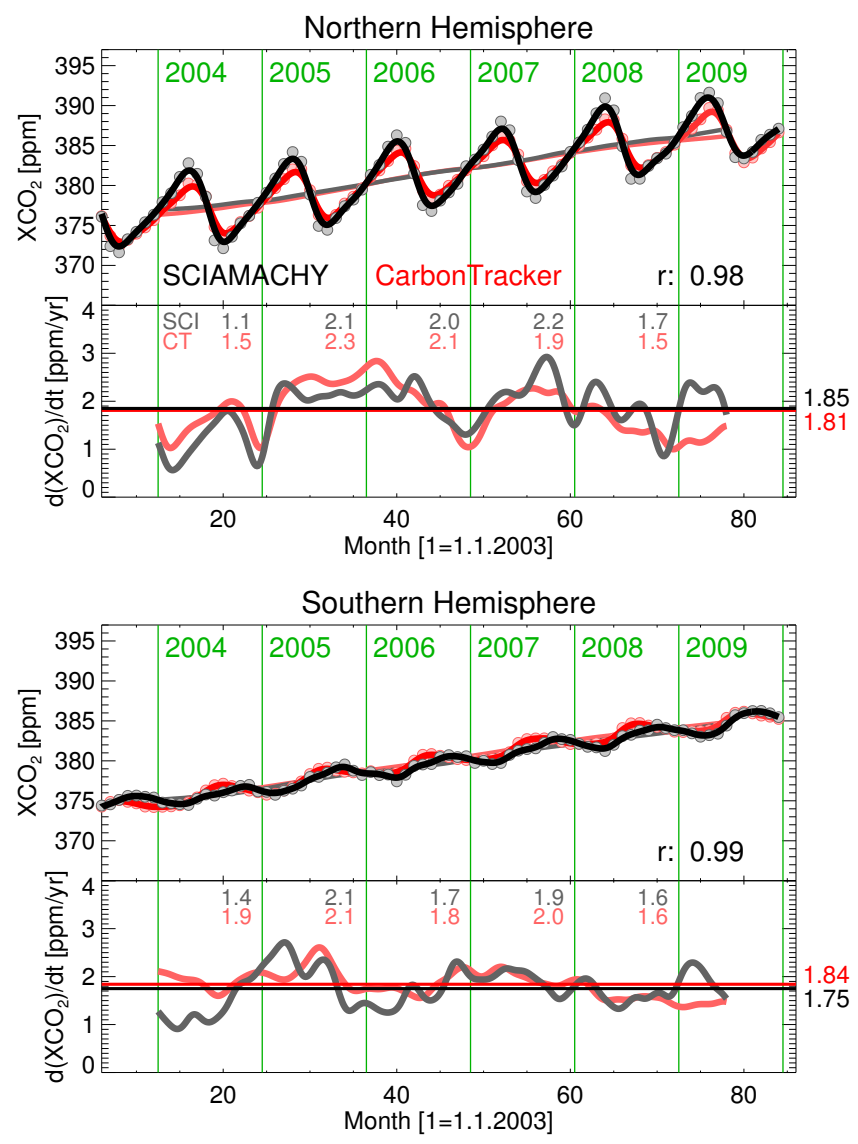

Fig. 1. The analysed SCIAMACHY $\mathrm{XCO}_{2}$ data set (black) compared to the assimilation system CarbonTracker (red) for the Northern Hemisphere (top) and the Southern Hemisphere (bottom) based on monthly means (circles). The saturated solid lines have been smoothed using a four-month Hann window (which has a similar frequency response to a two-month boxcar filter but better attenuation of high frequencies). The pale solid lines represent the corresponding deseasonalised trends derived using a 12-month running mean. Shown below are the derivatives of these deseasonalised curves corresponding to the current increase at the considered point in time. Also noted are yearly mean values of the derivatives (in pale colours) as well as the mean value of the whole time period on the right hand side. The retrieved steady increase of atmospheric carbon dioxide of just less than $2 \mathrm{ppmyr}^{-1}$ is attributed to anthropogenic emissions and quantitatively in line with CarbonTracker.

River Delta including the megacity Shanghai, which is one of the most densely populated regions on earth and the centre of Chinese productivity and economic growth. The maps show averages of all the SCIAMACHY $\mathrm{XCO}_{2}$ retrievals for the years 2003-2009 over the respective region (gridded $0.5^{\circ} \times 0.5^{\circ}$, effective resolution $\sim 2^{\circ} \times 2^{\circ}$ after smoothing) compared to the Emission Database for Global Atmospheric Research (EDGAR v4.2, Olivier et al., 2012) for the period 2003-2008 displayed on the same grid. As can be seen, there is reasonable agreement in the broad spatial distribution of SCIAMACHY $\mathrm{XCO}_{2}$ and EDGAR anthropogenic $\mathrm{CO}_{2}$ emissions bearing in mind that exactly identical patterns of retrieved $\mathrm{XCO}_{2}$ and anthropogenic emissions cannot be expected because of transport and atmospheric mixing. An advanced analysis aiming at smaller and less intense emission regions would require a three-dimensional (3-D) atmospheric transport model.

To quantify the regional $\mathrm{CO}_{2}$ mole fraction enhancement, source and background regions are defined, respectively (yellow and teal polygons in Fig. 2). The source and reference region are centered at the same latitude in each case to eliminate solar zenith angle dependencies as a potential source of error. The yearly enhancements are defined as the yearly mean value of the background region subtracted from the mean value of the source region. Also shown are the yearly emission enhancements from the EDGAR database for comparison based on summing up the emissions for the source and background regions, respectively. It can be observed, that all considered source regions exhibit stable enhancements compared to the respective reference region for all years. As a consequence, the mean enhancements averaged over all years are statistically significant for all cases and are $1.5 \pm 0.7 \mathrm{ppm}$ for the Rhine-Ruhr metropolitan region and the Benelux, $1.8 \pm 0.7 \mathrm{ppm}$ for the East Coast of the United States, and 3.9 $\pm 2.1 \mathrm{ppm}$ for the Yangtze River Delta.

The larger standard deviation of the retrieved Yangtze River Delta enhancement is due to a distinct positive trend, which is consistent with anthropogenic emissions from the EDGAR database. For the other two regions there is no obvious trend, neither for the retrieved $\mathrm{XCO}_{2}$ enhancement nor for the corresponding EDGAR emission enhancement. Besides the consistent trend for the Yangtze River Delta, the comparable emission enhancement of the US East coast and the Rhine-Ruhr region is also reflected in comparable retrieved $\mathrm{XCO}_{2}$ enhancements underlining the consistency of the satellite results with the emission database.

The retrieved estimates are in accordance with the order of magnitude that is expected for anthropogenic $\mathrm{CO}_{2}$ signals. For example, Palmer et al. (2008) show using the GEOS-Chem model that the anthropogenic $\mathrm{XCO}_{2}$ enhancement along the US East Coast is typically $1-2 \mathrm{ppm}$ at the model resolution of $2.0^{\circ} \times 2.5^{\circ}$, which is similar to our effective resolution. Another model study estimates $\mathrm{CO}_{2}$ columnaveraged mole fraction enhancements of up to $2 \mathrm{ppm}$ over selected metropolitan areas (Pacala et al., 2010). Kort et al. (2012) deduce enhancements of $3.2 \pm 1.5 \mathrm{ppm}$ for Los Angeles and $2.4 \pm 1.2 \mathrm{ppm}$ for Mumbai using GOSAT measurements. Ground-based total column measurements in the densely populated urban region of Southern California including Los Angeles and the surrounding suburbs provide column enhancements attributed to anthropogenic emissions of 2-8 ppm (Wunch et al., 2009). 

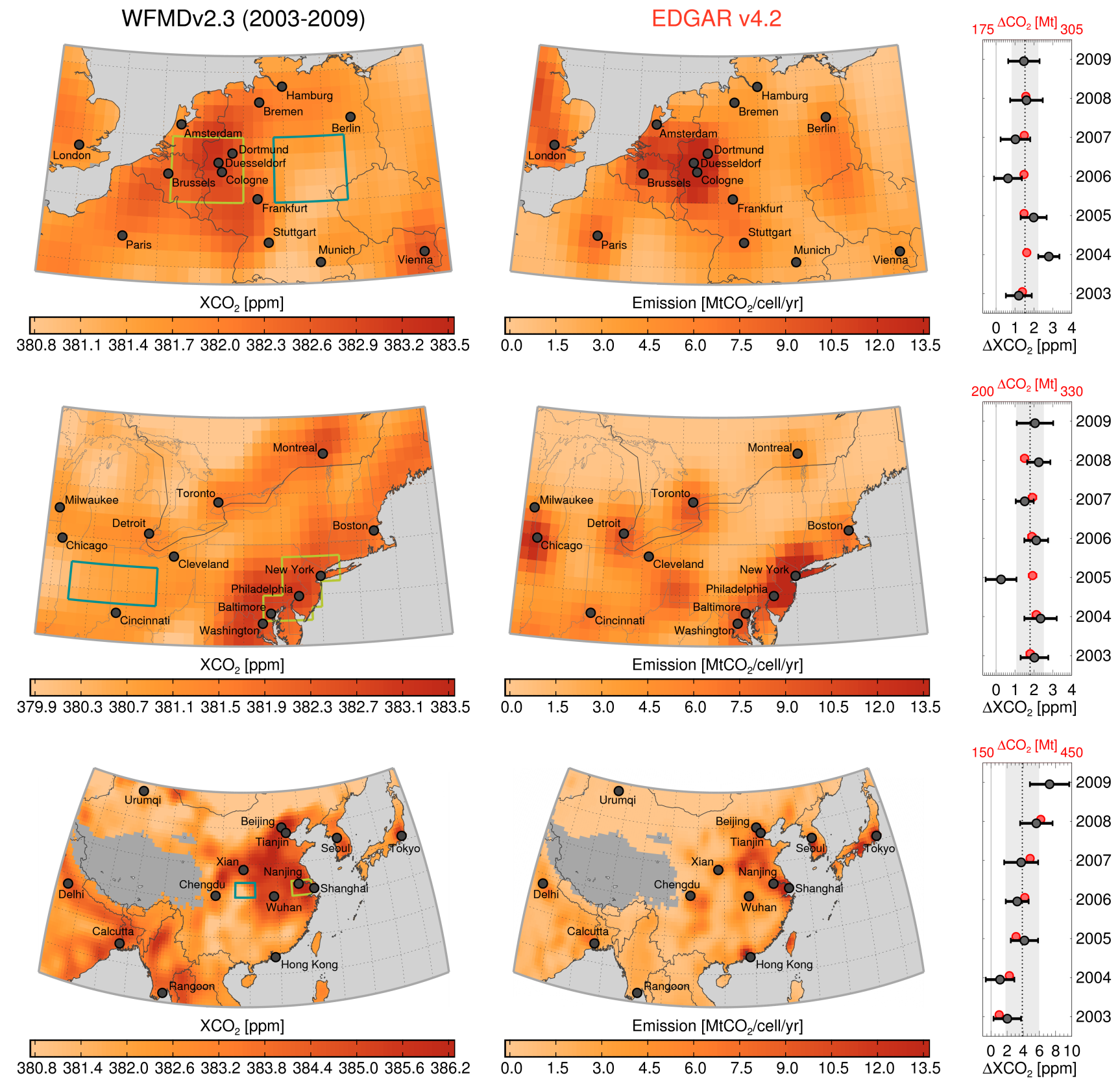

Fig. 2. SCIAMACHY $\mathrm{XCO}_{2}$ (left) and EDGAR anthropogenic $\mathrm{CO}_{2}$ emissions (middle) for several regions. To quantify the regional $\mathrm{XCO} 2$ enhancement source and background regions are defined, respectively (yellow and teal polygons). The yearly enhancements shown as symbols in the right panel are defined as the yearly mean value of the background region subtracted from the mean value of the source region using the root sum square of the corresponding standard deviations as error bars. The dotted lines represent the mean enhancements averaged over all years and the shaded areas the corresponding standard deviations. Also shown are the yearly emission enhancements from the EDGAR database in red.

\subsection{Discussion of potentially contributing error sources}

\subsubsection{Aerosols and albedo}

As aerosols and albedo potentially differ between urban and background regions, Figs. 3 and 4 show aerosol optical depth
(AOD) reanalysis data generated within the European GEMS (Global and regional Earth-system Monitoring using Satellite and in-situ data) project (Morcrette et al., 2009; Benedetti et al., 2009), which have been sampled at the time and location of the SCIAMACHY measurements, as well as retrieved albedo at $760 \mathrm{~nm}$ and $1570 \mathrm{~nm}\left(\mathrm{O}_{2}\right.$ and $\mathrm{CO}_{2}$ fitting window $)$ 

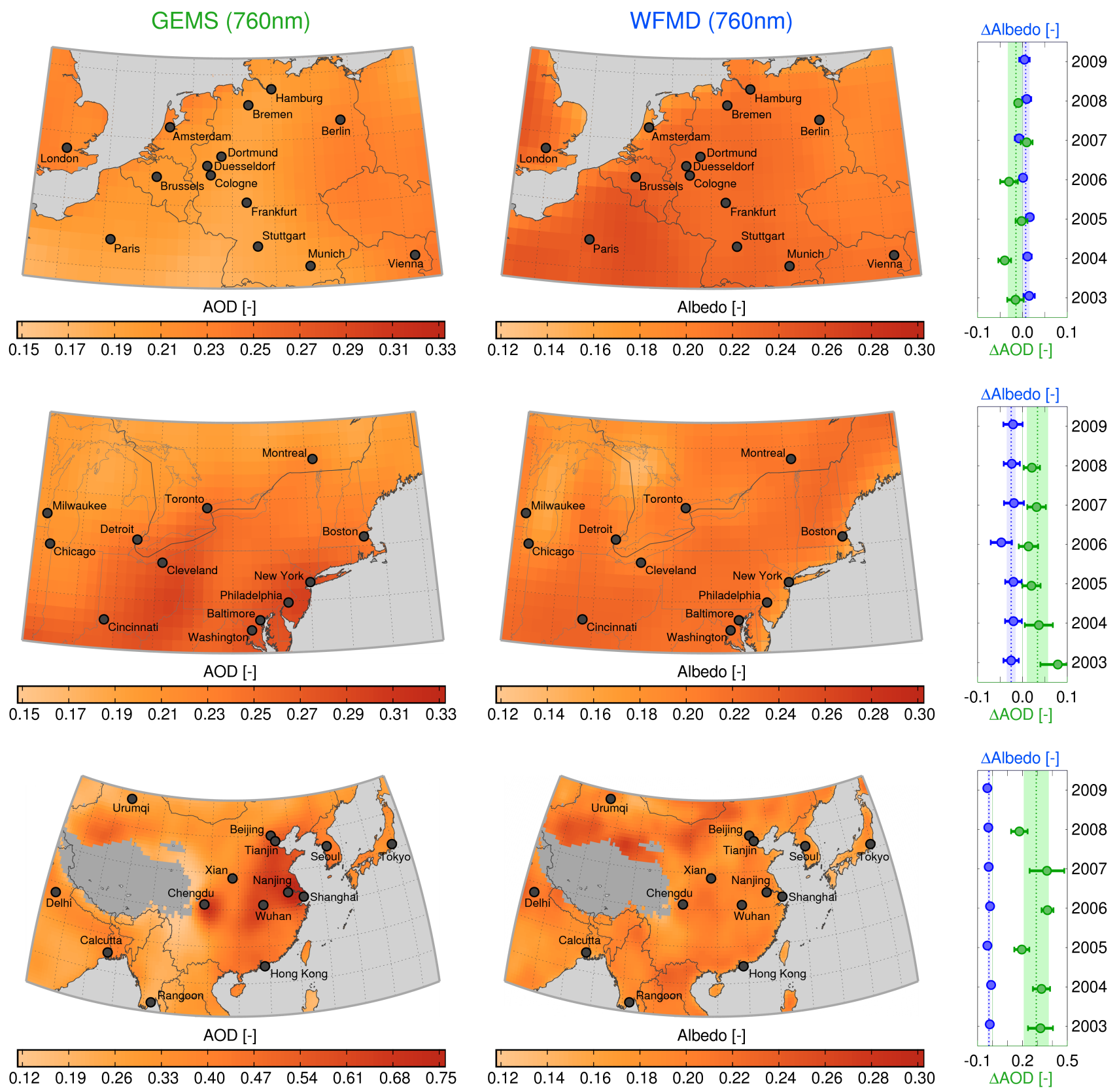

Fig. 3. Aerosol optical depth reanalysis data generated within the European GEMS project (left) and retrieved albedo at $760 \mathrm{~nm}$ (middle) for the considered regions to analyse potential contributions of aerosol and albedo to the retrieved $\mathrm{XCO}_{2}$ enhancement over the selected source regions. The symbols in the right panel represent the yearly differences of the mean values in the source and background regions introduced in Fig. 2 using the root sum square of the corresponding standard deviations as error bars. The dotted lines represent the average of all years and the shaded areas the corresponding standard deviations.

for the considered regions to analyse potential contributions of aerosol and albedo to the retrieved $\mathrm{XCO}_{2}$ enhancement over the selected source regions. The global GEMS reanalysis data set, which is based on assimilation of MODIS (MODerate resolution Imaging Spectroradiometer) aerosol information, has been downloaded from http://data-portal. ecmwf.int/data/d/gems_reanalysis/ and converted to SCIAMACHY overpass time and the desired wavelengths as described in Heymann et al. (2012a).

Similar to the $\mathrm{XCO}_{2}$ enhancements, the yearly differences of the mean aerosol and albedo values in the respective source and background regions introduced in Fig. 2 are 

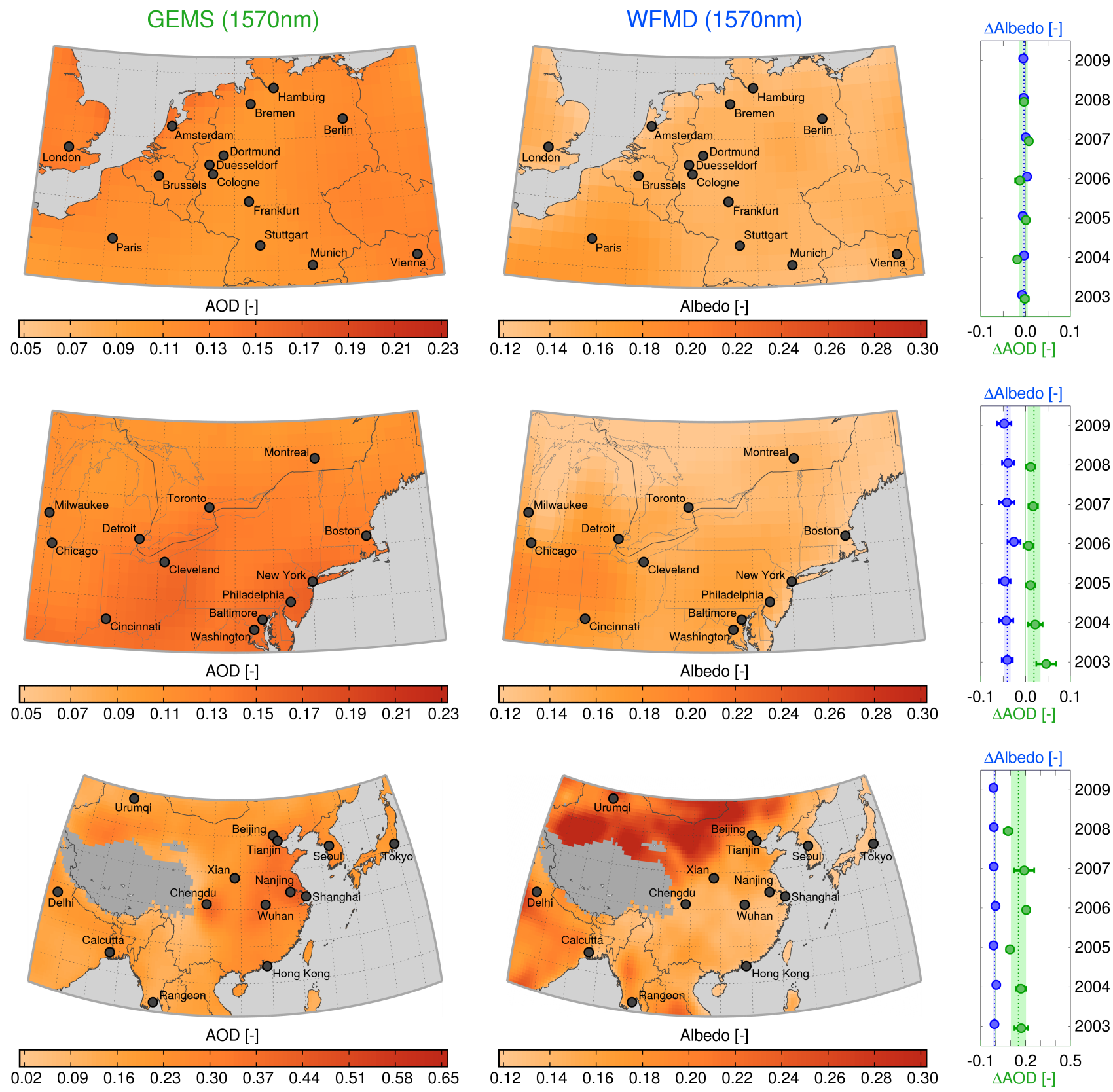

Fig. 4. As Fig. 3 but for $1570 \mathrm{~nm}$.

calculated and depicted. With the exception of aerosol optical depth over the Yangtze River Delta the averaged yearly differences are too small to induce a significant contribution to the retrieved $\mathrm{XCO}_{2}$ enhancements derived in the previous subsection.

The case of the Yangtze River Delta has to be analysed in more detail because there is a distinct enhancement of AOD when comparing source and reference region values $(\Delta \mathrm{AOD} \approx 0.3$ at $760 \mathrm{~nm})$. An indication that the enhancement is actually not dominated by aerosol errors is the fact that the retrieved positive trend, which is consistent with EDGAR, is not reflected in the yearly AOD enhancements, i.e. there is no trend in the GEMS AOD differences of source and background averages, which would be the prerequisite, if aerosol errors were the main contribution.

The potential overestimation of the retrieved regional anthropogenic $\mathrm{XCO}_{2}$ enhancement over the Yangtze River Delta due to aerosols is evaluated quantitatively using radiative transfer simulations (see Table 1). Thereby, the aerosol profiles shown in Fig. 5, which are consistent with GEMS 
Table 1. Evaluation of the potential overestimation of the retrieved regional anthropogenic $\mathrm{XCO}_{2}$ enhancement due to aerosols in the case of the Yangtze River Delta based on simulated measurements. In the radiative transfer simulations the aerosol profiles shown in Fig. 5, which are consistent with GEMS AOD, and the averaged retrieved albedos for the source and background region are used to estimate the resulting percentual $\mathrm{CO}_{2}$ and $\mathrm{O}_{2}$ column errors. The calculations are performed for a solar zenith angle of $30^{\circ}$, which is approximately the mean value in both regions.

\begin{tabular}{lccr}
\hline Yangtze River Delta & $\begin{array}{c}\mathrm{CO}_{2}(\%) \\
(\mathrm{Alb} 0.14)\end{array}$ & $\begin{array}{c}\mathrm{O}_{2}(\%) \\
(\mathrm{Alb} 0.20)\end{array}$ & $\mathrm{XCO}_{2}(\mathrm{ppm})$ \\
\hline Source region & 0.1 & -0.8 & 3.3 \\
Background & 0.2 & -0.2 & 1.5 \\
\hline Source - Background & & 1.8 \\
Relative regional regression correction & -1.5 \\
\hline Potential overestimation of anthropogenic & 0.3 \\
enhancement due to aerosols & \\
\hline
\end{tabular}

AOD, and the averaged retrieved albedos for the source and background region are used. We assume an aerosol type consisting of $50 \%$ soot and about $50 \%$ water soluble aerosol, as well as traces of insoluble aerosol (dust) in the lowest $10 \mathrm{~km}$. The calculations are performed for a solar zenith angle of $30^{\circ}$, which is approximately the mean value in both regions. The simulated potential $\mathrm{XCO}_{2}$ enhancement of the source region relative to the background region due to aerosols amounts to $1.8 \mathrm{ppm}$. On the other hand, it has to be borne in mind that this is the estimate before the multivariate linear regression correction described in Sect. 2. The analysis of uncorrected and corrected real satellite data reveals that the retrieved $\mathrm{XCO}_{2}$ enhancement is reduced by $1.5 \mathrm{ppm}$ due to the regression correction in the case of the Yangtze River Delta. Hence, it can be concluded that the resulting potential overestimation of the anthropogenic $\mathrm{XCO}_{2}$ enhancement due to aerosols amounts to about $0.3 \mathrm{ppm}$, which does not affect the significance of the retrieved enhancement. These results suggest that the introduced multivariate linear regression is capable to compensate for retrieval errors due to aerosols. Consequently, the regression correction impact on the retrieved $\mathrm{XCO}_{2}$ over Central Europe and the US East Coast, where the AOD source and background differences are much smaller, is marginal compared to China.

Although aerosols are not considered explicitly in the linear regression, the compensation for aerosol related errors mainly comes in through the combination of the radiance and the column error terms in the regression equation. An analysis of the difference of the WFMD retrievals to CarbonTracker confirms that the correlation with GEMS AOD is actually significantly reduced after the linear regression.

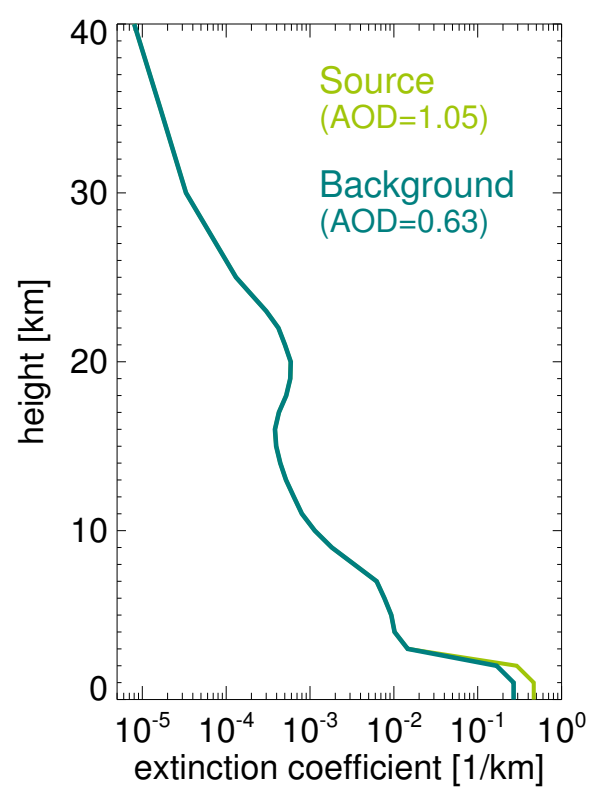

Fig. 5. Aerosol extinction profiles at $550 \mathrm{~nm}$ used in the radiative transfer simulations to estimate the potential overestimation of the retrieved regional anthropogenic $\mathrm{XCO}_{2}$ enhancement due to aerosols in the case of China. We use an anthropogenic aerosol type consisting of $50 \%$ soot and about $50 \%$ water soluble aerosol, as well as traces of insoluble aerosol (dust) in the lowest $10 \mathrm{~km}$. Note that the extinction coefficient is shown on a logarithmic scale. Also given are corresponding aerosol optical depths at $550 \mathrm{~nm}$.

\subsubsection{Heterogeneous sampling and residual biospheric signals}

Another potential error contribution is the $\mathrm{CO}_{2}$ seasonal cycle in combination with heterogeneous sampling in space and time. For example, one could imagine that the source and reference regions are unevenly sampled because of quality filtering, e.g. cloud screening. This possible effect is expected to cancel out to a large extent by averaging over several years. At least, it should be already included in the error estimates given in Sect. 3.1 unless the sampling differences are highly systematic for different years. Hence, significant differences of the enhancement estimates due to heterogeneous sampling are not expected for multi-year averages.

To draw more quantitative conclusions, the biogenic influence (seasonal cycle, see Fig. 1) is minimised by subtracting the monthly mean values of the satellite $\mathrm{XCO}_{2}$ for the supersets (map extracts of Figs. 2-4) containing the respective source and reference regions of interest from the single measurements before averaging. This approach also separates potential issues due to the $\mathrm{CO}_{2}$ increase with time from the enhancement estimates. The same analysis as described above is then repeated for these anomalies, which are expected to be free of residual biospheric signals, revealing that the spatial patterns are virtually unchanged, i.e. the 
Table 2. Retrieved enhancements (with $1 \sigma$ error) and corresponding trends for the discussed source regions relative to the respective reference regions for the biospheric corrected anomalies and the original data set (numbers in brackets). Estimates shown in italic are statistically not significant.

\begin{tabular}{lccrr}
\hline & \multicolumn{2}{c}{ Enhancement $(\mathrm{ppm})$} & \multicolumn{2}{c}{ Trend $\left(\mathrm{ppmyr}^{-1}\right)$} \\
\hline Rhine-Ruhr region & $1.3 \pm 0.7$ & $(1.5 \pm 0.7)$ & $-0.1 \pm 0.1$ & $(-0.1 \pm 0.1)$ \\
US East Coast & $1.1 \pm 0.5$ & $(1.8 \pm 0.7)$ & $0.0 \pm 0.1$ & $(0.0 \pm 0.1)$ \\
Yangtze River Delta & $2.4 \pm 0.9$ & $(3.9 \pm 2.1)$ & $0.3 \pm 0.2$ & $(0.8 \pm 0.4)$ \\
\hline
\end{tabular}

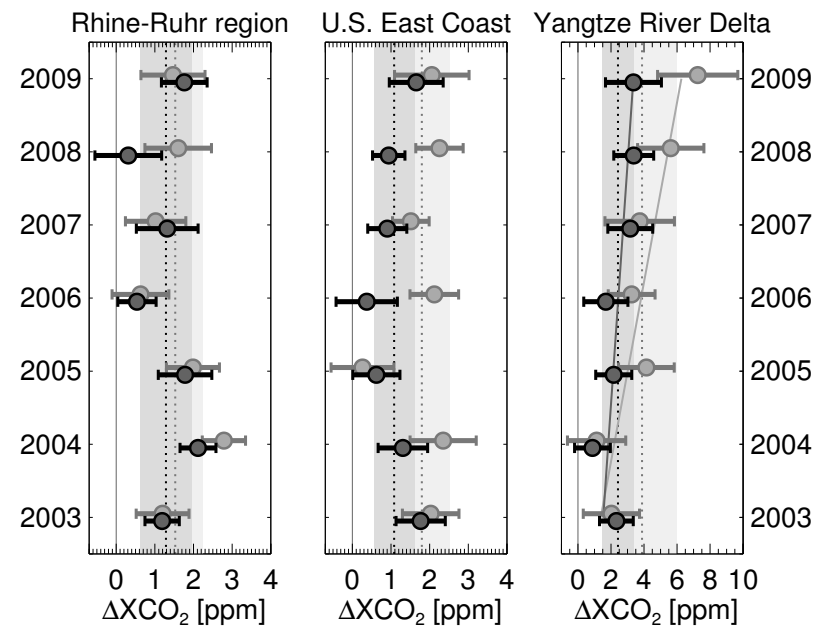

Fig. 6. Comparison of the retrieved yearly enhancements for the discussed source regions relative to the respective reference regions for the original data set (grey) and the biospheric corrected anomalies (black), which are obtained by subtracting large-scale regional monthly means from the single measurements. The dotted lines represent the mean enhancements averaged over all years and the shaded areas the corresponding standard deviations. Also shown are the linear fits demonstrating the positive trend of the Yangtze River Delta enhancement. Quantitative estimates of retrieved enhancements and corresponding trends are listed in Table 2.

retrieved $\mathrm{XCO}_{2}$ enhancements are still significant for all regions. However, the values of the retrieved enhancements can differ quantitatively from the results presented above. Nevertheless, the differences of the estimates based on the two different analysis methods (original data set and biospheric corrected anomalies) are not significant when using multi-year averaging. Specifically, we derive $1.3 \pm 0.7 \mathrm{ppm}$ for the Rhine-Ruhr metropolitan region and the Benelux, $1.1 \pm 0.5 \mathrm{ppm}$ for the East Coast of the United States, and $2.4 \pm 0.9 \mathrm{ppm}$ for the Yangtze River Delta when analysing the biospheric corrected anomaly data. Thus, we typically derive somewhat smaller enhancements and standard deviations when filtering out residual biospheric signals.

A detailed comparison of the retrieved enhancements for both methods is given in Table 2 and Fig. 6 . As can be seen, the positive trend of the retrieved enhancement observed for the Yangtze River Delta is less pronounced when using the biospheric corrected anomalies (in particular due to smaller enhancements in the years 2008 and 2009, where heterogeneous sampling seems to play a larger role in this region) but is still significant. To quantify the Yangtze River Delta trends we fit the yearly enhancements weighted according to the estimated yearly enhancement errors (also shown in Fig. 6). The associated trend error is then derived from the square root of the covariance of the linear fit parameter. The derived trend for the Yangtze River Delta amounts to $0.3 \pm 0.2 \mathrm{ppm} \mathrm{yr}^{-1}$ for the biospheric corrected anomalies and $0.8 \pm 0.4 \mathrm{ppm} \mathrm{yr}^{-1}$ for the original data set. Compared to the absolute mean enhancement, the Yangtze River Delta $\mathrm{XCO}_{2}$ anomaly enhancement trend corresponds to about $13 \pm 8 \%$ per year. This is quantitatively consistent with the relative EDGAR emission enhancement trend which amounts to $10 \pm 1 \%$ per year for this region. In unison, there are no significant $\mathrm{XCO}_{2}$ or EDGAR emission enhancement trends for the other two regions.

\section{Conclusions}

It was shown by analysing SCIAMACHY nadir measurements over the largest emitting conurbations of Europe, America, and Asia that anthropogenic $\mathrm{CO}_{2}$ emissions can be detected from space and that emission trends might be tracked using satellite observations. Future wide swath imaging satellite instruments with higher spatial resolution, like the candidate Earth Explorer Opportunity Mission CarbonSat, will allow to extend the current analysis of large and intense emission regions to more localised emission sources. In this sense, the presented results can be interpreted as a first step towards the projected capability of future satellite instruments for better disentangling natural and anthropogenic carbon emissions and for monitoring and independent verification of $\mathrm{CO}_{2}$ emissions down to the point-source scale, e.g. power plants.

We derived statistically significant $\mathrm{XCO}_{2}$ enhancements for the Rhine-Ruhr metropolitan region and the Benelux, the East Coast of the United States, and the Yangtze River Delta with order of magnitude of the enhancements being in agreement with what is expected for anthropogenic $\mathrm{CO}_{2}$ signals. Additionally, we found a significant positive trend for the Yangtze River Delta enhancement and no trends for the other 
regions, which is consistent with anthropogenic emissions from EDGAR.

An analysis of potential contributions caused by retrieval errors due to aerosol and albedo has shown that aerosol and albedo variability typically cannot explain the observed enhancements. In the particular case of China, with very strong aerosol loading and correlation of the spatial aerosol and $\mathrm{XCO}_{2}$ enhancement patterns, the potential influence estimated by radiative transfer simulations is compensated by the introduced multivariate linear regression correction of the retrieved $\mathrm{CO}_{2}$ column-averaged mole fraction data. Heterogeneous sampling in combination with seasonally varying biospheric signals can influence the estimated $\mathrm{XCO}_{2}$ enhancements quantitatively. However, the corresponding differences are not significant for the considered source regions when averaging over several years and all qualitative conclusions remain unchanged. This provides confidence that the retrieved signals actually point to anthropogenic $\mathrm{CO}_{2}$ emissions because the combination of systematic retrieval errors due to aerosols and sampling effects can be excluded as an alternative explanation of the observed variations.

The objective of establishing a scientific basis for policy assessment in the future would benefit from a comprehensive monitoring system of accurate in-situ (surface, aircraft, balloons) and remote sensing (satellites, aircraft) measurements. Combining the different methods in a multiscale analysis system will be a significant prospective research topic.

Acknowledgements. We thank ESA and DLR for providing us with the SCIAMACHY Level 1 data and the SCIAMACHY calibration team (DLR, SRON, University of Bremen, ESA, and others) for continuously improving the quality of the spectra. CarbonTracker results were provided by NOAA ESRL, Boulder, Colorado, USA from the website at http://carbontracker.noaa.gov/. The anthropogenic emissions have been obtained from the Emission Database for Global Atmospheric Research (EDGAR), release version 4.2, of the European Commission's Joint Research Centre (JRC) http://edgar.jrc.ec.europa.eu/). We thank the European GEMS project for providing the global aerosol data set http: //data-portal.ecmwf.int/data/d/gems_reanalysis/).

The research leading to these results has received funding from the ESA projects CARBONGASES, GHG-CCI, and ADVANSE, the DLR grant SADOS, and from the University and the State of Bremen.

Edited by: B. N. Duncan

\section{References}

Benedetti, A., Morcrette, J.-J., Boucher, O., Dethof, A., Engelen, R. J., Fisher, M., Flentje, H., Huneeus, N., Jones, L., Kaiser, J. W., Kinne, S., Mangold, A., Razinger, M., Simmons, A. J., and Suttie, M.: Aerosol analysis and forecast in the European Centre for Medium-Range Weather Forecasts Integrated Forecast System: 2. data assimilation, Geo- phys. Res. Lett., 114, D13205, doi:10.1029/2008JD011115, 2009.

Boesch, H., Baker, D., Connor, B., Crisp, D., and Miller, C.: Global characterization of $\mathrm{CO}_{2}$ Column Retrievals from shortwave-infrared satellite observations of the Orbiting Carbon Observatory-2 mission, Remote Sens., 3, 270-304, doi:10.3390/rs3020270, 2011.

Bovensmann, H., Burrows, J. P., Buchwitz, M., Frerick, J., Noël, S., Rozanov, V. V., Chance, K. V., and Goede, A.: SCIAMACHY Mission objectives and measurement modes, J. Atmos. Sci., 56, 127-150, 1999.

Bovensmann, H., Buchwitz, M., Burrows, J. P., Reuter, M., Krings, T., Gerilowski, K., Schneising, O., Heymann, J., Tretner, A., and Erzinger, J.: A remote sensing technique for global monitoring of power plant $\mathrm{CO}_{2}$ emissions from space and related applications, Atmos. Meas. Tech., 3, 781-811, doi:10.5194/amt-3-781-2010, 2010.

Burrows, J. P., Hölzle, E., Goede, A. P. H., Visser, H., and Fricke, W.: SCIAMACHY - Scanning imaging absorption spectrometer for atmospheric chartography, Acta Astronaut., 35, 445-451, 1995.

Chevallier, F., Bréon, F.-M., and Rayner, P. J.: Contribution of the orbiting carbon observatory to the estimation of $\mathrm{CO}_{2}$ sources and sinks: theoretical study in a variational data assimilation framework, J. Geophys. Res., 112, D09307, doi:10.1029/2006JD007375, 2007.

Crisp, D., Atlas, R. M., Bréon, F.-M., Brown, L. R., Burrows, J. P., Ciais, P., Connor, B. J., Doney, S. C., Fung, I. Y., Jacob, D. J., Miller, C. E., O'Brien, D., Pawson, S., Randerson, J. T., Rayner, P., Salawitch, R. S., Sander, S. P., Sen, B., Stephens, G. L., Tans, P. P., Toon, G. C., Wennberg, P. O., Wofsy, S. C., Yung, Y. L., Kuang, Z., Chudasama, B., Sprague, G., Weiss, P., Pollock, R., Kenyon, D., and Schroll, S.: The Orbiting Carbon Observatory (OCO) mission, Adv. Space Res., 34, 700-709, 2004.

Heymann, J., Schneising, O., Reuter, M., Buchwitz, M., Rozanov, V. V., Velazco, V. A., Bovensmann, H., and Burrows, J. P.: SCIAMACHY WFM-DOAS $\mathrm{XCO}_{2}$ : comparison with CarbonTracker $\mathrm{XCO}_{2}$ focusing on aerosols and thin clouds, Atmos. Meas. Tech., 5, 1935-1952, doi:10.5194/amt-5-1935-2012, 2012a.

Heymann, J., Bovensmann, H., Buchwitz, M., Burrows, J. P., Deutscher, N. M., Notholt, J., Rettinger, M., Reuter, M., Schneising, O., Sussmann, R., and Warneke, T.: SCIAMACHY WFM-DOAS $\mathrm{XCO}_{2}$ : reduction of scattering related errors, Atmos. Meas. Tech., 5, 2375-2390, doi:10.5194/amt-5-2375-2012, 2012 b.

Houweling, S., Breon, F.-M., Aben, I., Rödenbeck, C., Gloor, M., Heimann, M., and Ciais, P.: Inverse modeling of $\mathrm{CO}_{2}$ sources and sinks using satellite data: a synthetic inter-comparison of measurement techniques and their performance as a function of space and time, Atmos. Chem. Phys., 4, 523-538, doi:10.5194/acp-4523-2004, 2004.

Hungershoefer, K., Breon, F.-M., Peylin, P., Chevallier, F., Rayner, P., Klonecki, A., Houweling, S., and Marshall, J.: Evaluation of various observing systems for the global monitoring of $\mathrm{CO}_{2}$ surface fluxes, Atmos. Chem. Phys., 10, 10503-10520, doi:10.5194/acp-10-10503-2010, 2010.

Keppel-Aleks, G., Wennberg, P. O., O’Dell, C. W., and Wunch, D.: Towards constraints on fossil fuel emissions from total column 
carbon dioxide, Atmos. Chem. Phys. Discuss., 12, 29887-29913, doi:10.5194/acpd-12-29887-2012, 2012.

Kort, E. A., Frankenberg, C., Miller, C. E., and Oda, T.: Space-based observations of megacity carbon dioxide, Geophys. Res. Lett., 39, L17806, doi:10.1029/2012GL052738, 2012.

Kuze, A., Suto, H., Nakajima, M., and Hamasaki, T.: Thermal and near infrared sensor for carbon observation Fourier-transform spectrometer on the greenhouse gases observing satellite for greenhouse gases monitoring, Appl. Optics, 48, 6716-6733, doi:10.1364/AO.48.006716, 2009.

McKain, K., Wofsy, S. C., Nehrkorn, T., Eluszkiewicz, J., Ehleringer, J. R., and Stephens, B. B.: Assessment of groundbased atmospheric observations for verification of greenhouse gas emissions from an urban region, P. Natl. Acad. Sci. USA, 109, 8423-8428, doi:10.1073/pnas.1116645109, 2012.

Miller, C. E., Crisp, D., DeCola, P. L., Olsen, S. C., Randerson, J. T., Michalak, A. M., Alkhaled, A., Rayner, P., Jacob, D. J., Suntharalingam, P., Jones, D. B. A., Denning, A. S., Nicholls, M. E., Doney, S. C., Pawson, S., Boesch, H., Connor, B. J., Fung, I. Y., O'Brien, D., Salawitch, R. J., Sander, S. P., Sen, B., Tans, P., Toon, G. C., Wennberg, P. O., Wofsy, S. C., Yung, Y. L., and Law, R. M.: Precision requirements for space-based $\mathrm{X}_{\mathrm{CO}_{2}}$ data, J. Geophys. Res., 112, D10314, doi:10.1029/2006JD007659, 2007.

Morcrette, J.-J., Boucher, O., Jones, L., Salmond, D., Bechtold, P., Beljaars, A., Benedetti, A., Bonet, A., Kaiser, J. W., Razinger, M., Schulz, M., Serrar, S., Simmons, A. J., Sofiev, M., Suttie, M., Tompkins, A. M., and Untch, A.: Aerosol analysis and forecast in the European Centre for medium-range weather forecasts integrated forecast system: forward modeling, Geophys. Res. Lett., 114, D06206, doi:10.1029/2008JD011235, 2009.

Olivier, J. G. J., Janssens-Maenhout, G., and Peters, J. A. H. W.: Trends in global $\mathrm{CO}_{2}$ emissions, 2012 Report, PBL Netherlands Environmental Assessment Agency, The Hague, Joint Research Centre, Ispra, ISBN 978-92-79-25381-2, 2012.

Pacala, S. W., Breidenich, C., Brewer, P. G., Fung, I., Gunson, M. R., Heddle, G., Law, B., Marland, G., Paustian, K., Prather, M., Randerson, J. T., Tans, P., and Wofsy, S. C.: Verifying Greenhouse Gas Emissions: Methods to Support International Climate Agreements, The National Academies Press, Washington, DC, 2010.

Palmer, P. I., Barkley, M. P., and Monks, P. S.: Interpreting the variability of space-borne $\mathrm{CO}_{2}$ column-averaged volume mixing ratios over North America using a chemistry transport model, Atmos. Chem. Phys., 8, 5855-5868, doi:10.5194/acp-8-5855-2008, 2008.

Peters, W., Jacobson, A. R., Sweeney, C., Andrews, A. E., Conway, T. J., Masarie, K., Miller, J. B., Bruhwiler, L. M. P., Pétron, G., Hirsch, A. I., Worthy, D. E. J., van der Werf, G. R., Randerson, J. T., Wennberg, P. O., Krol, M. C., and Tans, P. P.: An atmospheric perspective on North American carbon dioxide exchange: CarbonTracker, P. Natl. Acad. Sci. USA, 104, 1892518930, doi:10.1073/pnas.0708986104, 2007.

Peters, W., Krol, M. C., van der Werf, G. R., Houweling, S., Jones, C. D., Hughes, J., Schaefer, K., Masarie, K. A., Jacobson, A. R., Miller, J. B., Cho, C. H., Ramonet, M., Schmidt, M., Ciattaglia, L., Apadula, F., Heltai, D., Meinhardt, F., di Sarra, A. G., Piacentino, S., Sferlazzo, D., Aalto, T.,
Hatakka, J., Ström, J., Haszpra, L., Meijer, H. A. J., van der Laan, S., Neubert, R. E. M., Jordan, A., Rodó, X., Morguí, J.A., Vermeulen, A. T., Popa, E., Rozanski, K., Zimnoch, M., Manning, A. C., Leuenberger, M., Uglietti, C., Dolman, A. J., Ciais, P., Heimann, M., and Tans, P. P.: Seven years of recent European net terrestrial carbon dioxide exchange constrained by atmospheric observations, Glob. Change Biol., 16, 1317-1337, doi:10.1111/j.1365-2486.2009.02078.x, 2010.

Rayner, P. J. and O'Brien, D. M.: The utility of remotely sensed $\mathrm{CO}_{2}$ concentration data in surface inversions, Geophys. Res. Lett., 28, 175-178, 2001.

Schneising, O., Buchwitz, M., Burrows, J. P., Bovensmann, H., Reuter, M., Notholt, J., Macatangay, R., and Warneke, T.: Three years of greenhouse gas column-averaged dry air mole fractions retrieved from satellite - Part 1: Carbon dioxide, Atmos. Chem. Phys., 8, 3827-3853, doi:10.5194/acp-8-3827-2008, 2008.

Schneising, O., Buchwitz, M., Reuter, M., Heymann, J., Bovensmann, H., and Burrows, J. P.: Long-term analysis of carbon dioxide and methane column-averaged mole fractions retrieved from SCIAMACHY, Atmos. Chem. Phys., 11, 28632880, doi:10.5194/acp-11-2863-2011, 2011.

Schneising, O., Bergamaschi, P., Bovensmann, H., Buchwitz, M., Burrows, J. P., Deutscher, N. M., Griffith, D. W. T., Heymann, J., Macatangay, R., Messerschmidt, J., Notholt, J., Rettinger, M., Reuter, M., Sussmann, R., Velazco, V. A., Warneke, T., Wennberg, P. O., and Wunch, D.: Atmospheric greenhouse gases retrieved from SCIAMACHY: comparison to ground-based FTS measurements and model results, Atmos. Chem. Phys., 12, 1527-1540, doi:10.5194/acp-12-1527-2012, 2012.

Solomon, S., Qin, D., Manning, M., Chen, Z., Marquis, M., Averyt, K. B., Tignor, M., and Miller, H. L. (Eds.): Climate change 2007: The physical science basis, Contribution of working group I to the Fourth Assessment Report of the Intergovernmental Panel on Climate Change (IPCC), Cambridge University Press, Cambridge, UK, 2007.

Velazco, V. A., Buchwitz, M., Bovensmann, H., Reuter, M., Schneising, O., Heymann, J., Krings, T., Gerilowski, K., and Burrows, J. P.: Towards space based verification of $\mathrm{CO}_{2}$ emissions from strong localized sources: fossil fuel power plant emissions as seen by a CarbonSat constellation, Atmos. Meas. Tech., 4, 2809-2822, doi:10.5194/amt-4-2809-2011, 2011.

Wunch, D., Wennberg, P. O., Toon, G. C., Keppel-Aleks, G., and Yavin, Y. G.: Emissions of greenhouse gases from a North American megacity, Geophys. Res. Lett., 36, L15810, doi:10.1029/2009GL039825, 2009.

Wunch, D., Wennberg, P. O., Toon, G. C., Connor, B. J., Fisher, B., Osterman, G. B., Frankenberg, C., Mandrake, L., O’Dell, C., Ahonen, P., Biraud, S. C., Castano, R., Cressie, N., Crisp, D., Deutscher, N. M., Eldering, A., Fisher, M. L., Griffith, D. W. T., Gunson, M., Heikkinen, P., Keppel-Aleks, G., Kyrö, E., Lindenmaier, R., Macatangay, R., Mendonca, J., Messerschmidt, J., Miller, C. E., Morino, I., Notholt, J., Oyafuso, F. A., Rettinger, M., Robinson, J., Roehl, C. M., Salawitch, R. J., Sherlock, V., Strong, K., Sussmann, R., Tanaka, T., Thompson, D. R., Uchino, O., Warneke, T., and Wofsy, S. C.: A method for evaluating bias in global measurements of $\mathrm{CO}_{2}$ total columns from space, Atmos. Chem. Phys., 11, 12317-12337, doi:10.5194/acp11-12317-2011, 2011. 